\section{PUBLIC-PRIVATE ARBITRATION \\ IN ROMANIAN LAW}

\author{
Daniela CÎMPEAN
}

Roxana VORNICU

Dacian C. DRAGOȘ

\section{Daniela CÎMPEAN}

Lecturer, Department of Business, Faculty of Business,

Babeș-Bolyai University, Cluj-Napoca, Romania

E-mail: dana.cimpean@ubbcluj.ro

\section{Roxana VORNICU}

Postdoctoral Fellow, King's College, London, United Kingdom E-mail: roxana.vornicu@kcl.ac.uk

Dacian C. DRAGOȘ (corresponding author)

Professor, Department of Public Administration and Management / Center for Good Governance Studies, Faculty of Political, Administrative and Communication Sciences,

Babeș-Bolyai University, Cluj-Napoca, Romania

Tel.: 0040-264-431.361

E-mail:dragos@fspac.ro
DOI: $10.24193 /$ tras.64E.2

Published First Online: 10/28/2021

\title{
Abstract
}

The article endeavors to introduce the constitutional and statutory framework for arbitration in Romania, whilst discussing the dilemmatic legislative provisions allowing for public entities to become parties in an arbitration dispute. It includes a discussion of the concept of administrative contracts in Romania and a chronological analysis of the evolution of public-private arbitration under administrative contracts. Some of the landmark Romanian public-private arbitrations under international investment treaties have held the public agenda in recent years and they shape the public debate on arbitration as fit for purpose when it comes to public contracts.

Keywords: arbitration, public entities, public-private arbitration, Romania, administrative contracts. 


\section{Introduction}

Public-private arbitration is of great importance and great practical relevance in Romania and one of the main reasons behind it lies in the great number of public works contracts concluded in our country, many of which contain an arbitration clause. After the fall of the communist regime and, moreover, after Romania's accession to the European Union, the reconstruction of the country had to be done by means of public works contracts, be they concession contracts, public-private partnerships, or public procurement of works. Most of the time, such contracts took the shape of an internationally used standard contractual model, like the FIDIC model, which includes arbitration as the dispute resolution mechanism. This was a solution often found acceptable by both the financing institutions as well as the foreign investors.

However, this reality has always stood in great tension with a strong French inspired public-private divide in our administrative law system. In addition, some of the creators of Romania's modern administrative legal system, have outspokenly positioned themselves against arbitration (especially international arbitration) as an effective means to resolve disputes whilst protecting the public interest (Iorgovan, 2004), and this has set the trend for public-private arbitration in our country for many years.

Nevertheless, there is a wind of change, albeit it is hard to pinpoint the exact factor that led to it. For more than a decade, contracts between a public and a private party could not include arbitration as their dispute resolution system, but this has finally changed in 2013 and stayed as such in the past six years. In this paper we will first make a general presentation of the constitutional and statutory framework for arbitration, whilst discussing the dilemmatic legislative provisions allowing for public entities to become parties in an arbitration dispute. We will tackle this under section 2, which will also include a presentation of the concept of administrative contracts in Romania and a chronological analysis of the evolution of public-private arbitration under administrative contracts. In section 3 we will briefly refer to some of the landmark Romanian public-private arbitrations under international investment treaties and section 4 will tackle arbitration as dispute resolution in our country with a focus on the aspects that have a particularity when it comes to public-private arbitration. Finally, we will look at arbitration as governance and list some conclusive remarks (section 5).

\section{Public-private arbitration in Romania}

\subsection{The Constitutional and statutory framework for arbitration in Romania}

The historic origins of arbitration in Romania date back to the $19^{\text {th }}$ century, as it was introduced through the provisions of the 1865 Civil Procedure Code. This code was inspired mostly by French and Swiss civil procedure rules. Under the 1865 Civil 
Procedure Code, arbitration was regulated under Book IV, which was substantially amended in 1993, after the Constitutional reform (Leaua and Baias, 2016). This civil law reform entailed bringing Romania's legal provisions on arbitration more in line with the principles and the structure of the UNCITRAL Model Law of 1985 (Csaki, 2018).

After the fall of the communist regime in 1989, Romania went through a constitutional reform in 1991 and another one in 2003. The currently in force Constitution recognizes citizens' 'right to access the remedies system', but only refers to judicial courts (art. 21).

Access to the remedies system in Romania entails bringing claims before specialized tribunals; Romanian courts and tribunals are of different levels (first instance courts, tribunals, courts of appeal, High Court of Cassation and Justice) and have specialized jurisdiction (such as administrative, civil, criminal, insolvency, etc.). For instance, the administrative jurisdiction in Romania is a specialized jurisdiction and claims for annulment of administrative acts and award of damages caused through illegal administrative action should be brought exclusively before specialized administrative courts. This has been applicable also to disputes arising from the performance of administrative/ public contracts, but, currently, this is no longer the case. We will refer to this in detail under sections 3 and 4 below. However, judges ruling on all these cases belong to the same body of magistrates. They do not have specialized training prior to starting their activity as administrative or civil judges but undergo what could be called a de facto specialization. When a judge is promoted from a Tribunal to a Court of Appeal, they tend to keep this de facto specialization although sometimes, in practice, in small cities throughout the country, a judge might go from ruling in the administrative court to hold office in civil courts due to lack of personnel or managerial policies. In practice, these specialized courts/tribunals are in fact specialized units/departments of the Tribunals, Courts of Appeal and of the Supreme Court (in Romania, the High Court of Cassation and Justice) and function in the same premises with other courts. The enforcement of arbitral awards is performed by civil units of the courts.

As mentioned, the Constitution does not expressis verbis state that justice can be done through arbitral tribunals. However, art. 146, point d) of the current Constitution indirectly recognizes arbitral tribunals as part of the national system of dispute resolution, by allowing them to raise exceptions of unconstitutionality concerning laws and ordinances in front of the Constitutional court. The exception of unconstitutionality is an instrument of constitutional law that allows the parties of a dispute pending before a court of justice or an arbitral tribunal to request the Constitutional Court to review the compatibility with the Constitution of a certain statutory provision that is applicable in the pending dispute. The exception of unconstitutionality is not regulated under the Constitution but under Law no. 47/1992 on the functioning of the Constitutional Court. 
Specifically, art. 146, point d) under the Constitution reads that the Constitutional Court's attributions include: 'ruling on the exception of unconstitutionality of ordinances and laws raised before judicial courts and commercial arbitral tribunals' (authors' translation).

We should first clarify why the Constitution refers to commercial arbitral tribunals. This is mostly because the previously in force Civil Code in Romania had established a dual system that was very much centered around the dichotomy civil law/commercial law. After the 2013 reform, the New Civil and Civil Procedure Codes have established a monist system in which there is no longer a civil/commercial law dichotomy (Piperea, 2011). As a consequence, it was stated by scholars that the constitutional expression 'commercial arbitral tribunal' is no longer compatible with the monist Romanian private law system and thus should be revised (Puie, 2015). We subscribe to this observation.

Furthermore, the Constitutional Court has ruled in numerous decisions on the constitutionality of arbitration (in general, not in the specific case of public-private arbitration). For instance, the court held that 'arbitration is an exception to the principle that justice is done through the courts', and that it 'represents a legal mechanism, designed to ensure an impartial, faster, less formal and confidential legal process finalized by an enforceable judgment' (Decision no. 203/2006). When confronted with the question of whether arbitral tribunals are infringing the constitutional prohibition on the establishment of extraordinary courts, the Court stated that arbitral tribunals do not fall under the category of extraordinary courts, since the procedure they follow neither violates nor restricts the procedural rights of the parties, previsioned in the Civil Procedure Code or any other rights or freedoms. Moreover, it ascertained the fact that the Constitution itself in article 146, point d), recognizes the existence of the arbitral tribunals (Decision no. 8/2007).

In February 2013 a New Code of Civil Procedure (hereinafter referred to as the New Code of Civil Procedure - NCCP) entered into force and the provisions on arbitration previously regulated under Book IV under the Code of Civil Procedure were replaced with the current Book IV, articles 541-621. The rules laid down in the New Code of Civil Procedure are, by and large, a restatement of the previously in force rules (Csaki, 2018).

The legal nature of arbitration in the Romanian legal system is that of an 'alternative dispute resolution system' that should be conducted in accordance with procedural rules that are derogatory from the lex generalis (i.e., the general civil procedure rules). The NCCP establishes that parties to an arbitral dispute are free to choose the rules applicable to a dispute provided such rules are not contrary to public order and imperative legal provisions (art. $541 \mathrm{NCCP}$ ).

The NCCP's Book IV includes seven titles, dedicated to the general principles of arbitration: the definition of arbitration; the regulation of the conditions in which the subjects of law, including those of public law (art. 542, para. 2 and 3), may agree to solve their disputes by arbitration; the general provisions concerning the arbitral 
tribunal; the arbitral procedure; the review of the arbitral decision by the regulation of the institution of judicial control; and the enforcement of arbitral decision. Finally, the last title of the book tackles institutionalized arbitration (regulated for the first time in the NCCP, 2010).

As a general rule, the NCCP establishes that disputes involving matters such as the civil status of persons, collective labor conflicts, certain shareholders' disputes, annulment of intellectual property rights or bankruptcy proceedings cannot be subject to arbitration and thus, arbitration agreements purporting to cover such disputes are null and void (art. 542 (1) NCCP).

As far as public-private arbitration is concerned, art. 542 contains very important provisions that read: 'the State and public bodies have the right to enter arbitral agreements only if expressly authorized by law or international conventions that Romania is a party to'. In other words, for public authorities, the rule is not having the right to enter into arbitral agreements and the exception is being expressly authorized to do so. A contrary rule applies to 'public entities that undertake economic activities'. The NCCP provides that they have the right to enter arbitral agreements, unless expressly prohibited by law or the rules applicable to their establishment and functioning (art. 542 (3) NCCP).

This provision is quite puzzling as it makes a distinction between two concepts that can be, on occasion, interchangeable, namely public authorities and public entities that undertake economic activities. In fact, de lege ferenda, these concepts should be clarified, as the provisions under art. 542 (2) and (3) are susceptible of great uncertainty (Ciobanu, 2014). First of all, the civil procedure rules themselves do not specify what the concept of public entities that undertake economic activities actually entails. Still, some interpretative reference points could be found in the Civil Code's definition of public authorities and the Civil Code's definition of commercial activities. Under the provisions of art. 3 of the Civil Code a commercial activity is one 'undertaken by professionals who systematically exercise an activity dealing with producing, administering or selling goods, services, irrespective of whether this is done in a lucrative scope or not' This debate is still open under national law but a reasonable interpretation is that the provisions under art. 542 (3) NCCP referring to public entities that undertake economic activities should be interpreted consistently with the concept of public enterprises as designed by the Government Emergency Ordinance no. 109/2011 on good governance of public enterprises. This statutory act contains a definition of public enterprises and, as per art. 2 of the Ordinance, it includes: (a) public enterprises that are created by the State or a municipality; (b) national companies or companies whose sole or majority shareholder is the state or a municipality; (c) companies that have as main shareholders one of the enterprise's mentioned under letters a) and b) above or are under the control of such companies (Ciobanu, 2014).

For the purposes of this paper, it should be underlined that the general rule in matters of public arbitration is that the state and the public bodies do not have the right to enter arbitration agreements unless expressly allowed to; the reason behind 
this solution lies in the strong Romanian public-private divide and the specificities of Romanian administrative jurisdiction. For instance, one of the principles applicable to the resolution of administrative disputes by administrative tribunals is that the protection of the general public interest always takes precedence over contractual freedom. This is stipulated under art. 8 of Law no. 554/2004 on judicial review of administrative action.

Law no. 554/2004 on judicial review of administrative action sets the bases of Romanian administrative law. Law no. 554/2004 establishes the detailed conditions and general legal framework for review of illegal administrative action. It includes procedural law and substantial administrative law provisions and, although it is not a proper administrative code, it is the general act applicable to the functioning of the Romanian administration. Unlike French administrative law, in the Romanian legal system, judicial review of administrative action entails the possibility to bring both a claim for annulment of the illegal administrative act as well as a claim in damages through the same procedure (contentieux de pleine juridiction). Law no. 554/2004 also defines the concept of 'administrative contract' and, for the purposes of this paper, this is a very important aspect.

There has been great debate in Romanian scholarship and much uncertainty as to whether administrative contracts can be subject to arbitration or not. Historically, the concept of administrative contract has been known in Romanian law since the interwar period, but it was eliminated once the communist regime was installed, since it was considered incompatible with the new social order. The concept entered the Romanian legal system via French law (Puie, 2014). After the fall of the communist regime, the concept had a shy comeback since the first statutory act on judicial review of administrative action did not define, nor mention it (Law no. 29/1990). Finally, in 2004, art. 2 (1) under Law no. 544/2004 established that administrative contracts were assimilated to the notion of administrative act and by administrative contract we should intend: 'contracts that have as object the exploitation of public property, the performance of public interest works, public services and public procurement'. The same definition is applicable today with the addition that, currently, Law no. 544/2004 mentions that 'other types of administrative contracts may be regulated by statutory acts' (art. 2 (1) c1, Law no. 554/2004). Public procurement contracts, concession contracts, and general public-private partnerships belong to this category, so the concept has much practical relevance. The Romanian legislator has oscillated many times between deciding either that (i) commercial courts had jurisdiction to solve disputes regarding the performance of public contracts or that, on the contrary, (ii) administrative courts have jurisdiction to rule on disputes regarding the performance of public contracts. Whenever the legislator decided that the first rule was applicable (i.e., commercial courts had jurisdiction to solve disputes regarding the performance of public contracts), scholars and courts of justice agreed that public contracts could be subject to arbitration. Whenever the legislator decided to apply the second rule, then disputes arising from the performance of a public body where considered non-arbitrable 
(Oglinda, 2014). All such disputes can currently be subject to arbitration. We will develop this in the following section.

\subsection{Administrative contracts and their 'arbitrability'}

In Romanian doctrine, scholars use the concept of 'arbitrability' of a dispute when referring to the possibility to bring a dispute before the arbitral tribunal (Ciobanu, 2017). There are two conditions that need to be met for a dispute to be arbitrable, namely: (i) the nature of the dispute needs to be patrimonial, and (ii) the rights that make the object of the dispute need to be tradeable. Regarding the patrimonial nature of a dispute, it is necessary to know whether its object can be assessed, directly or indirectly, in monetary values. As to 'tradability' of rights, alongside classical disputes that cannot be subject to arbitration such the marital status, civil capacity, the inheritance debate, family relations, art. 542 (1) of the NCCP includes 'rights upon which parties cannot decide'. As far as public-private arbitration is concerned, the crux of the debate lies in whether aspects of public (administrative) law may be included in this last category (for the opinion that it cannot, see Ciobanu, 2017). Another generating source for the debate on whether such disputes were arbitrable or not concerned the nature of the contracts concluded between public entities and private parties. In the period between 1990 until 2004 they were considered commercial contracts and, thus, the disputes arising from their performance were considered arbitrable, whereas after the entry into force of Law no. 554/2004 they were qualified as administrative contracts and, thus, disputes arising thereof were considered non-arbitrable. In other words, the nature of the contract determined the jurisdiction of the court ruling on disputes arising thereof (commercial or administrative) which, in its turn, determined the arbitrability of the disputes.

The first act that explicitly allowed parties to a public contract to choose arbitration was Law no. 15/1990 concerning the reorganization of the state economic units as public companies and private companies, but that limited this opportunity to the disputes between this specific type of companies - public companies. Later on, Law no. 219/1998 on concessions explicitly provided the right of the parties to include an arbitration clause in the contract between them (Bacanu, 2008). Law no. 219/1998 regulated domain concessions, service concessions and works concessions since, at that time, the EU acquis on concessions had not been implemented yet in Romania (but only later, in 2006).

As a consequence, starting with 1990 and until 2004, when Law no. 554/2004 on judicial review of administrative action entered into force, disputes arising from the performance of contracts between public entities and private entities could be subject to arbitration. Once Law no. 554/2004 entered into force, the concept of administrative contract came back to the Romanian system and disputes arising thereof could not be brought before an arbitral tribunal, as it was only administrative courts that had jurisdiction over disputes arising out of the performance of such contracts. The legislator's intention was to deliberately exclude administrative contracts from arbi- 
tration. A renowned Romanian administrative law scholar, Antonie Iorgovan, who was acknowledged as one of the main authors of this statutory act (Ciobanu, 2014) explained his conception of administrative contracts in one of his works and stated the ratio legis for Law no. 554/2004. He argued against 'privatization' of traditional public law regimes' (Iorgovan, 2004, p. 5).

Unfortunately, Professor Iorgovan was successful in imposing his very strong public law views for many years since he was also twice a Member of Parliament. Due to pressure coming from foreign investors and financing institutions, the legislation would eventually change but not until 2013.

As it is well known, Romania became a member of the EU in 2007 but we have begun implementing the EU acquis earlier. In 2006, Romania transposed the EU public procurement legislation through a single legislative instrument, i.e., Government Emergency Ordinance no. 34/2006 (GEO no. 34/2006). Initially, GEO no. 34/2006 stipulated that public procurement and concession contracts could not be subject to arbitration. It did not exclude such possibility expressis verbis, but the courts that had jurisdiction over disputes arising over such contracts were the administrative ones, which lead scholars to state and courts to rule on the incompatibility between arbitration and administrative contracts. This was within the line of Law no. 554/2004 and Professor Iorgovan's philosophy. For instance, in 2010, the High Court of Cassation and Justice established that 'inserting an arbitral clause in a public procurement contract' was illegal. In the same decision, the supreme court established that the illegality of the arbitration clause in a public procurement contract could be invoked ex officio by the court (Decision no. 3483/2010).

The change of perspective came in 2013, when Law no. 193/2013 modifying GEO no. 34/2006 came into force. This law introduced art. 288 under GEO no. 34/2006 that established that all the contracts regulated under GEO no. 34/2004 could be subject to arbitration. In the travaux preparatoires of the 2013 law modifying the regime of public procurement and concession contracts it was mentioned that this legislative revision was imposed due to the urgent need of flexibilization of the public procurement system and by the Memorandum concluded between the Romanian Government and the International Monetary Fund on the need of increasing Romania's efficiency and transparency in public procurement. Therefore, the introduction of arbitration as a dispute resolution mechanism for public contracts in 2013 was the result of international dialogue. Thus, it remained until present times. This has proven to be beneficial for the business reality of the country as foreign investors tend to feel more protected when they have access to an international arbitral court rather than being limited to national dispute resolution mechanisms (Kidane, 2017).

A brief parenthesis should be opened here. Public works contracts of higher value have followed a particular and special regime of their own throughout this entire period. As such, starting with 2008, the FIDIC standard contract forms have been made mandatory for all the works contracts that had a value above the threshold of the Procurement Directive (made mandatory through the Order of the Economy 
Ministry and the Public Works and Housing Ministry no. 915/465/415/2008). The value thresholds were those imposed by Directive 2004/18/EC. As it is well known, the FIDIC standard contract conditions establish international arbitration as the mechanism for dispute resolution applicable, whilst the applicable rules are those of the Paris ICC (sub-clause 20.6 under the General Conditions of Contract for PLANT and Design-Build). This has been the case with public works contracts concluded between contracting authorities (within the meaning of the public procurement legislation) and economic operators, in Romania, in the period between 2008 and 2010.

\subsection{Public-private arbitration and public procurement rules in Romania}

In 2014 there has been an EU reform of the public procurement law system (Directive 2014/24/EU on public procurement), Romania has implemented that legislation with four new laws in 2016, namely Law no. 98/2016 on public procurement, Law no. $99 / 2016$ on utilities procurement, Law no. 100/2016 on concession contracts and Law no. 101/2016 on remedies in the public procurement field. According to the later normative act, arbitration is now generally allowed in disputes arising out of the performance of public procurement and concession contracts. Furthermore, in 2018, the government approved a new standard contract form that is mandatory for all public works with a value above the thresholds stipulated under the public procurement legislation. This contract is a FIDIC inspired contract and states that disputes shall be settled by arbitration (Government Decision no. 1/2018 on the approval of the general and particular conditions of contract for certain categories of public procurement contracts related to the investment objectives financed by public funds).

This is a rule that has been applicable for many years in Romania, even prior to the entry into force of Government Decision no. 1/2018 approving the national standard contract model for public works.

Under the previous regimes, disputes arising out of the performance of these contracts were subject to international arbitration, whereas under Government Decision no. $1 / 2018$, they are currently subject to national arbitration. In the context of accessing European structural funds, the Romanian public authorities have signed, during the past years, an increased number of contracts of work execution, construction and design, based on FIDIC contracts. In these contracts, there are several standard clauses, and one of them concerns the resolution of disputes between parties through institutionalized arbitration, conducted by the International Court of Arbitration in Paris. The only issue that has raised contrary decisions is the competence of the arbitral tribunals. In many cases where the Court of International Commercial Arbitration from within the Chamber of Commerce and Industry of Romania (Law no. 335/2007 regarding the Romanian Chambers of Commerce) has received requests of dispute resolution by arbitration, grounded on a FIDIC contract, 'the procedure was closed or the action was dismissed on the basis of the jurisdiction clause of the Chamber of Commerce and Industry Paris, invoked by one of the parties of the contract' (Voicu, 2014). However, there are also arbitration decisions issued by the Court of International 
Commercial Arbitration from within the Chamber of Commerce and Industry of Romania, which state that:

in the absence of an explicit clarification in the content of the arbitration clause, the observation related to the Regulation of Commercial Arbitration of the Chamber of Commerce and Industry Paris does not include the choice by the parties of the competence of this arbitration court, but only the choice of the Procedural Rules that the arbitration tribunal - with competence over the disputes - will apply in designing and conducting the arbitration process' (Babiuc, 2012, p. 10).

For instance, the differences that emerged in the implementation of a FIDIC contract, signed by a Spanish legal person governed by private law with a local public authority from Romania, for the rehabilitation of several roads (Arbitration Decision no. 153 of 29 June 2010, unpublished). Since the works of the streets' rehabilitation were suspended, the contractor submitted an arbitration action before the Romanian Court of Arbitration, in order to be compensated for the damages caused by the Romanian contracting authority. As mentioned above, the Court held that it had jurisdiction to resolve the dispute because, in the absence of an explicit clarification concerning the assignment of the competence to the Court of Arbitration from within the Chamber of Commerce and Industry Paris, the parties could only have a say on the rules of procedure which the Arbitral Court would apply in the resolution of the dispute, not on the competence of the Court from Paris (Babiuc, 2012).

As mentioned, Government Decision no. 1/2018 brought a significant change in the regime applicable to the dispute resolution mechanisms of the public works contracts concluded in Romania in the sense that it imposed the Court of International Commercial Arbitration attached to the Chamber of Commerce and Industry of Romania as the venue for future disputes, as well as the rules of procedure enacted by this arbitral institution as the applicable ones. This change was regarded with skepticism by the construction industry and some scholars even question the constitutionality (and compatibility with the ECHR) of a normative administrative act imposing the venue and the rules for dispute resolution of all contracts (Government Decision no. $1 / 2018$ is a normative administrative act as per Romanian law) (Lefter and Pigui, 2017).

The travaux preparatoires of GD no. 1/2018 offer an explanation for the change, mentioning that:

'the arbitration organized by the Court of International Commercial Arbitration attached to the Chamber of Commerce and Industry of Romania is distinguished from the arbitration organized by other institutions, both national as well as international, in that it has a well-respected institutional reputation that was confirmed throughout time as well as the quality of the arbiters and its arbitral decisions, a reputation that this institution has built in direct connection with Romanian law and case law'. 
This explanation is redundant in the least, since all international arbitral institutions also have 'a well-respected institutional reputation'. Whilst beneficial for the institution itself, we believe this legislative measure is not beneficial for the Romanian construction industry as a whole as foreign investors are more comfortable knowing that they have the possibility of choosing international arbitration for disputes arising out of high value contracts.

\section{International arbitration involving the Romanian state}

As to international disputes, the European Convention on International Commercial Arbitration signed at Geneva in 1961 expressly states, in article 2, paragraph 1: 'the legal persons, qualified by the law that is applicable to them, as legal persons governed by public law, have the capacity to sign, in a valid way, arbitration agreements'. Other important international conventions referring to arbitration are The New York Convention of 1958 on The Recognition and Enforcement of Foreign Arbitral Decisions, ratified by Romania in 1961; the Washington Convention of 18 March 1965 , for the regulation of the disputes related to the investments between states and persons of other states, ratified in Romania in 1975. Article 11 of the Constitution (by which the Romanian State pledges to fulfil precisely and in good faith its obligations as deriving from the treaties in which it takes part) enables the application with priority of such international legal instruments into the Romanian legal order. This means that both the state, public authorities and legal persons organized under public law can consent to international arbitration even in the absence of a legislative provision allowing them to do so. This general permission also extends to arbitration under a contract. In this context, the question remains whether the Geneva Convention can be invoked only as regards to international arbitration arising from administrative contracts with the state and other public authorities (in other words contracts with a cross border interest) or also for domestic contracts with the state and public authorities. The arbitral tribunals have declined to adopt such a wide interpretation, stating that in the absence of a domestic law enabling arbitration, the Geneva Convention applies only to international arbitration (Arbitral Decision no. 177 of 4 July 2006, cited in Oglinda, 2014).

In the doctrine there are opinions that 'if a foreign party can insert in administrative contracts with the Romanian state an arbitration clause, treating Romanian parties differently would mean infringing on art. 16 of the Constitution on equality of rights' (Oglinda, 2014, p. 68). In that sense, the Geneva Convention has direct effect as to the possibility of state and other public authorities to consent to arbitration clauses in internal administrative contracts.

Going back to international arbitration involving the Romanian State, in the past years, there have been several complaints filed against Romania with the International Centre for Disputes Settlement Concerning the Investments from Washington. One such case has held and still holds the front page of the news. In the case ARB/05/20, 
the European Drinks Group Company won the case against the Romanian Government alleging infringement of provisions of the Bilateral Romanian-Swedish Agreement concerning the mutual protection of investments (Law no. 651/2002 ratifying The Agreement between the Government of Romania and the Government of the Kingdom of Sweden regarding the mutual protection and support of investments, signed on May 29, 2002). This violation consisted in the cancellation of the fiscal incentives granted for the investments made in the underprivileged area of Bihor County, whose value exceeded 200 million euros, as a result of Romania's accession to the EU. Following the Decision, the Romanian state was obliged to pay an amount of about 82 million euros to the European Drinks Group.

On the other hand, payment of damages was considered illegal state aid by the EU Commission, who sanctioned Romania for the portion of the amount that was already paid (Sandru and Ploesteanu, 2016; Matei, 2015). Following the Decision of the European Commission (Decision (EU) 2015/1470), several further court actions (T-624/15, European Food and others v. Commission; T-694/15, Micula v. Commission; T-704/15, Micula and others v. Commission) are pending (Matei, 2016, pp. 134141; Zerhdoud, 2014, pp. 1042-1052). The main issue here is the conflict between the arbitral decision and the Decision of the European Commission, with no clear solution in sight. However, in its Judgment of 18 June 2019, the General Court of the European Union annulled the Decision (EU) 2015/1470 of the European Commission, declaring that the Commission had no competence to apply EU State aid rules prior to Romania's accession to the EU (Cases T-624/15, T-694/15 and T-704/15).

A second-high profile case is a complaint filed against Romania by the Canadian company Gabriel Resources, a company that wanted to initiate gold mining activities (using cyanide) at Roșia Montană. The project was rejected by the Romanian Parliament in September 2013, mainly due to civic protests. The complaint against the Romanian Government regards the violation of the provisions of Romania's investment treaty with Canada. Gabriel Resources claimed that the authorities from our country 'blocked and prevented the implementation of the project, without a fair trial and without offering compensations, so that Gabriel Resources was actually completely deprived of the investments that they had made'1.

\section{Arbitration as dispute resolution in Romania}

\subsection{Appointment of arbitrators}

Romanian law makes no distinction between arbitration involving a public party and private-private arbitration, so the procedure is, at least theoretically, similar (art. 556 under the New Civil Procedure Code - NCPC). However, there are specificities

1 For a selection of newspaper articles on this topic and analyses of the dispute see [Online] http:// www.ziare.com/articole/proces+rosia+montana+rmgc 
attached to the very nature of public authorities. Thus, the appointment of arbitrators is at the will of the parties, with the observance of the principle of equality. Public bodies cannot enjoy any advantage that would derive from their special status in the procedure. The procedure of public authorities to appoint arbitrators may nevertheless be more complex than in the case of private parties, due to the specific of public law procedures - the need for collegial bodies to confirm a proposition by the executive body, for instance.

Art. 561 under the New Civil Procedure Code establishes the applicable rules in case the parties do not agree on the appointment of the single arbitrator, or in which a party does not appoint the arbitrator, or the arbitrators appointed by the parties fail to agree on the appointment of a person to serve as the president of the tribunal. As per art. 561 (1), in case of failed agreement, the decision will be taken by the tribunal which has territorial jurisdiction. This is applicable to both private as well as public private arbitration. However, there is a particularity applicable to public private arbitration when we are dealing with an administrative contract. As we have shown earlier, the administrative jurisdiction is separate from the civil one; therefore, the question in Romania is whether civil tribunals or administrative tribunals have jurisdiction to assign arbitrators for public-private cases. Administrative law judges would be more inclined to look for arbitrators that would understand the constraints deriving from public law, so that the decision rendered in the end is also enforceable.

The arbitrators must be independent and impartial to perform the tasks of resolving a particular dispute arising between the parties, by a final and compulsory decision for them both. Independence is an objective matter, while impartiality is a psychological, subjective one, and therefore more difficult to prove (Florescu, 2010). With regard to public-private arbitration, the provisions on incompatibilities and conflicts of interest in public office are of great interest (Law no. 161/2003), and need to be observed. The causes that may affect the independence and impartiality of the arbitrators are also referred to in art. 562 from the Code of Civil Procedure. The arbitrator is considered incompatible if he/she is a partner or a member of the management bodies of a legal person that 'has an interest in the cause' or if he/she is financially dependent on one of the parties, more specifically 'if the arbitrator has labor or service relations, respectively, or direct trade links with one of the parties, with a company controlled by one party or under joint control with it'. Finally, the conflict of interests also covers the situation when the arbitrator has previously provided consultancy services to one of the parties, assisted or represented one of the parties, or testified in one of the earlier phases of the case. Apart from these, cases of incompatibility provided by law in the case of judges are also applicable. The standards are not different in private or public-private arbitration though.

The Rules of the Chamber of Commerce and Industry of Romania should also be mentioned here, as they are more comprehensive than the New Civil Procedure Code rules. Art. 22, under the 2018 Rules of Arbitration currently in force, (CCIR, 2018; 
Stoica, 2019) establishes the following incompatibility cases:

1. any of the cases provided by the New Code of Civil Procedure with regard to judges;

2. the arbitrator does not meet the qualifications or conditions set out in the arbitration agreement;

3. the arbitrator is a shareholder, collaborator or director in a legal entity that has an interest in the case;

4. the arbitrator has a direct working or commercial relation with one of the parties, or with an entity controlled wholly or partially by one of the parties; or

5. the arbitrator has offered counsel to one of the parties or has assisted or represented one of the parties in the preliminary phases of that case.

\subsection{Representation of parties in the arbitral procedure}

The New Code of Civil Procedure allows the parties to the arbitration dispute to formulate requests and exercise their procedural rights in person or through a representative. GEO no. 26/2012 establishes how public entities can be represented before courts of justice (no distinction between international and domestic arbitration). According to the law, central or local public administrative authorities and institutions (regardless of their financing sources and reporting line), national corporations, national companies and companies fully or partially owned by the State, and government business enterprises that include in their organizational structure specialized legal experts cannot purchase legal expertise, assistance and/or representation. In other words, public entities cannot hire a lawyer if they are already paying for an in-house legal counsel.

The legal provisions, however, allow for the purchase of some services such as legal consulting, assistance and/or representation, but only if the public authorities and institutions cannot provide for it themselves (which is a qualitative assessment). This should be done with the approval of the financing entities for public administration or local deliberative bodies in case of local administration and subordinated companies (art. 1, para. 2 of GEO no. 26/2012). There is no tender procedure required - the procurement is based on the expertise and notoriety of lawyers. This is also because legal services are excluded from the EU and national public procurement regime. In other words, public bodies do not need to follow a competitive public procurement procedure every time they need to pay for legal services (art. 1 (2) d) under Directive 2014/24/EU).

In case of international arbitral disputes, Romania has a specific statutory instrument that establishes the procedure to be followed when acquiring legal assistance for representation before international arbitral tribunals, namely, Government Emergency Ordinance no. 126/2005. This act establishes that counsels will be appointed within 90 days as of receiving notice in an international dispute and that public procurement regulations will be followed to appoint such legal counsels. 


\subsection{The Kompetenz-Kompetenz principle in the arbitral procedure}

Although the arbitral procedure has many specific features which differentiate it from the judicial procedures, it resembles with the former in the sense that it usually follows the same steps: the written phase (notification), the oral phase (of the debates) and that of the deliberation and the ruling. According to art. 579 from NCCP, the arbitral tribunal has the obligation to assess, by default, during its first session, its own competence in solving the dispute (Timişoara Court of Appeal, Decision no. 1691/2011). This is an application of the principle known in the international doctrine as the 'Kompetenz-Kompetenz principle'.

The legal provisions do not distinguish between public-private and private-private arbitration; however, there are specificities for the former type of arbitration that we need to consider. Thus, the assessment of the arbitral tribunal takes into account both its own competence and the existence and validity of the arbitral clause. This assessment can be verified at the request of any interested person by courts. In the absence of such interested persons, the question is whether the State has an interest in verifying whether public-private arbitration involving, for instance, local authorities is not outside the legal limits. This may be done through the Prefect, the representative of the Government in the territory, who oversees the legality of local administration by filing judicial review actions (Law no. 215/2001 on local administration). If one of the parties of a dispute invokes the existence of an arbitral clause before the court, the court has the obligation to assess its own competence, and, if a valid arbitration clause exists, the court will transfer the case file to the arbitral tribunal (Mehedinti Court of Appeal, Decision no. 1081/2011).

Given the optional nature of the arbitration, the parties will determine themselves the rules of the arbitral procedure. The parties do not have the obligation to establish the rules of the arbitral procedure, but they have the option, either to establish them themselves or to give attorney power to the arbitrators to set the rules (art. 576, para. 1, NCCP). If the rules established by the parties are not complete, they will be completed by the rules established by the NCCP (art. 576, para. 1). In this context, it is worth noting that the Law on judicial review of administrative acts (art. 28, Law no. 554/2004) conditions the applicability in completion of rules from the NCCP to administrative law disputes on their compatibility with the specificity of the relations between public authorities and private parties, and the administrative judge is empowered to assess such compatibility. In other words, the judge can declare some rules of procedure to be unfit for the administrative law cases. There is no express provision that would pose the same conditionality for arbitration procedures, although as we have already shown above, administrative contracts are considered to be similar in legal regime with administrative acts (Law no.554/2004, art. 2). Nevertheless, we think that such a principle is applicable to arbitration as well, thus in public-private procedures arbitrators must consider the specifics of rights that can be disposed of by public authorities and decide accordingly. 
Moreover, arbitrators in public-private procedures must observe the legal impediments to a certain solution, even if such a solution would do justice to the parties. For instance, an arbitration on the issues of execution of a public procurement contract must not be detrimental to the initial, decision to award the contract to the winning bid. If by arbitral decision the conditions of award are modified and consequently other bidders might have a chance to win the contract, the arbitral decision will be quashed by the court. Taking into account the specifics of public law contracts does not mean that the principle of equal rights of the parties in arbitration is infringed. Our view is that equality of rights (art. 12, NCCP), in this context, refers to rights that can be disposed of or, in the case of public authorities, the list of such rights is inherently limited.

\subsection{Confidentiality of arbitral proceedings vs. the transparency obligation incumbent to public bodies}

The procedural means of judicial control that may be exercised on the arbitral decision is the appeal for annulment stipulated in art. 608 of the NCCP. The legal grounds of the appeal for annulment are expressly defined and limited, so they cannot be extended by analogy. They apply both in the case of private-private disputes and in the case of public-private ones.

The legal grounds for annulment are the following: the dispute is not capable of settlement through arbitration (art. 608, para. 1, point a), NCCP); the arbitration tribunal has settled a dispute without there being an arbitration agreement or based on a null or inoperative agreement; the arbitral tribunal has not been set in accordance with the arbitral agreement (art. 608, para. 1, point c), NCCP); the absence of one of the parties at the debates or the non-compliance of the summoning procedure; the ruling of the arbitral tribunal outside the legal deadline (art. 608, para. 1, point e), NCCP); extra petita (Bobei, 2013, p. 191); the absence of mandatory elements of the arbitral decision (art. 603, para. 1, NNCP). From the few case law it emerges that, most of the time, courts uphold the arbitral decision (Bucharest Court of Appeal, Decision no. 221/2015).

The most important ground for annulment in the context of public-private arbitration is when the arbitral ruling is contrary to public order, to accepted principles of morality, or to the provisions of the law. Both the arbitral convention and the arbitral decision must meet the specific requirements of public order, accepted principles of morality and of the imperative provisions of the law. This ground for annulment has relevance in the context of public-private arbitration, as some decisions of the arbitral tribunal, although grounded on equality, may be detrimental to public law imperatives. If the parts violate these rules when the arbitral agreement is signed, the latter is null. If the arbitral tribunal violates these rules, the decision can be annulled in court, on the basis of art. $608 \mathrm{NCCP}$. 


\subsection{Execution of arbitral decisions}

The arbitral decision is final and binding. In other words, 'the binding nature of the arbitral convention sets the binding nature of the arbitral decision in the relations between the contracting parties' (Ionaș-Sălăgean, 2001, p. 135). The competent court that decides on the declaration of enforceability verifies whether the decision has an enforceable nature. Within the appeal for annulment there is a possibility to verify whether the arbitral decision is in compliance with public order regulations, and the violation of the public order represents a reason for the annulment of the decision. As Romanian scholars point out, the claim for annulment is a procedure of judicial control 'meant to offer the parties guarantees regarding the solidity and legality of the arbitral decisions' (Ionaș-Sălăgean, 2001, p. 138).

The question here is whether arbitral tribunals can impose on public authorities to revoke or modify an administrative act as a result of arbitration. Under Romanian law, pursuant to a claim for judicial review of an administrative act, a court of justice can decide upon the illegality of the act but cannot impose the public body a certain conduct. In our opinion, the same rule should be applicable as regards arbitral tribunals.

As far as the enforcement of foreign arbitral decisions is concerned, art. 1124 under the New Civil Procedure Code stipulates that any foreign arbitral decision is recognized and can be executed in Romania if it meets two conditions: 1) the conflict constituting the subject of the dispute can be settled through arbitration in Romania; and 2) the decision does not contain provisions contrary to the public order regulations of Romanian private international law. In order to be forcefully executed, the foreign arbitral decision has to be recognized first. These conditions must be interpreted in accordance with the provisions of the New York Convention (1958) and those of the Geneva Convention (1961).

\section{The rule of law and public-private arbitration. Arbitration as governance. Concluding remarks}

Public-private arbitration in Romania raises two main issues: the arbitrability of regular administrative activities, and the arbitrability of administrative contracts, concluded between a private party and a state entity. As we have seen under section 2, Romanian law makes un unclear distinction between, on the one hand, the right to arbitration of 'the State and public bodies' and, on the other hand, the right to arbitration of 'public entities that undertake economic activities'. Whilst in the case of the first category the rule is that they do not have a right to arbitration unless expressly granted by law, in the other case, the rule is the opposite. This is an unfortunate distinction. First of all because it creates legal uncertainty, as the statutory act - New Code of Civil Procedure - imposing the differential regime, does not clarify either the meaning of the two concepts or the reason behind the different approach. Second of all, it is unfortunate because there is no constitutional or administrative law basis for giving the two types of entities a differential regime. Thus, currently, the rule ap- 
plicable is that disputes arising from administrative actions, as defined by law, cannot be settled through arbitration. The only body that can annul, in full or partially, the administrative act, is the Administrative Court resolving the dispute (Art. 18, para. 2, Law no. 554/2004 on judicial review of administrative action).

However, arbitration under administrative contracts is currently possible under Romanian law. As long as the jurisdiction over the settlement of disputes arising from unilateral administrative acts belongs exclusively to the national courts and the possibility of setting up an arbitral tribunal arises only in case of administrative contracts, we consider that the use of arbitration does not lead to the violation of any democratic principle; on the contrary, it is the expression of a well-functioning free and democratic society.

Regarding the free access to justice, stipulated by the Romanian Constitution, the existence of alternative methods of dispute resolution, such as arbitration, does not, in any way, violate this constitutional principle. This was also acknowledged by the Romanian Constitutional Court, in 2006, through a Decision where it showed that the arbitration dispute resolution system enhances the parties' right to access to justice, since it is based on their choice and, furthermore, the arbitral decision can be subject to a court of justice's judicial review. The Court also decided that '(...) arbitral tribunals do not breach or restrict the parties' right to access to justice or any other rights under the civil procedure code or the constitution' (Constitutional Court Decision no. 395/2006).

All fundamental principles of the rule of law also apply in the case of arbitration proceedings. Among these principles, the most important are the principle of equal treatment of the parties, the right to an independent and fair trial, and the appropriate notification procedure. Romania has ensured the respect of these guarantees through the extensive regulation of the arbitration institution within the New Code of Civil Procedure. Art. 541, para. 2, NCCP states that 'the litigation parties and the arbitral tribunal have the possibility to establish derogating rules of procedure from the ordinary law, provided that those rules are not contrary to the public order regulations and the statutory provisions of the law'.

As to the differences that could exist between a judgement delivered by a court and an arbitration decision, in an identical case, we should mention that in Romania judicial practice is not uniform. Despite the ECHR's rulings in this regard (i.e. ECHR case Stefan and Stef v. Romania), the Romanian legislator did not find a solution to this problem. As far as the judicial practice is not unitary all throughout the system and the Romanian legislator does not take any steps to change this, the differences between the judgement delivered by a court and an arbitral tribunal's decision cannot be seen as contrary to the law, since there are still many and constant differences in how courts of justice tackle the same legal issue.

In conclusion, public-private arbitration is possible but still limited in Romania, and the procedure is identical to that applicable to private disputes. Scholarship is, however, somewhat divided when it comes to arbitration and public interest. The 
contributors arguing that arbitration might be inadequate for dealing with matters of public interest tend to be those dealing with administrative law alone and also disciples of Antonie Iorgovan, who has influenced for so many years the Romanian administrative law arena (Ciobanu, 2014), whereas those arguing that arbitration is in fact adequate, tend to be scholars, and practicing lawyers at the same time (Oglinda, 2014).

\section{References:}

1. Babiuc, V., 'O chestiune de competență’ [A Matter of Competence], 2012, Revista Română de Arbitraj (Romanian Review of Arbitration), no. 21, pp. 10-14.

2. Bacanu, I., 'Soluționarea prin arbitraj a litigiilor izvorâte din contractele de achiziție publică, de concesiune de lucrări publice și de servicii, precum și din contractele de concesiune de bunuri proprietate publică' [Arbitration Settlement of Disputes Arising from Public Procurement, Public Works and Service Contracts, as Well as from Public Property Concessions], 2008, Revista Română de Arbitraj (Romanian Review of Arbitration), no. 1, pp. 7-14.

3. Bobei, R.B., Arbitrajul intern și internațional [Internal and International Arbitration], Bucharest: C.H. Beck, 2013.

4. Chamber of Commerce and Industry of Romania (CCIR), 'Rules of Arbitration', 2018, [Online] available at http://arbitration.ccir.ro/regulile-de-procedura-arbitrala/, accessed on September 9, 2020.

5. Ciobanu, A.S., 'Arbitrabilitatea litigiilor din materia contractelor de concesiune, în lumina noului Cod de procedură civilă’ [Arbitrability of Litigation in the Field of Concession Contracts, in the Light of the New Code of Civil Procedure], 2014, Revista Română de Drept Privat, no. 5, pp. 49-72.

6. Csaki, T., 'The Romanian Chapter', in Carter J. (ed.), The International Arbitration Review, $7^{\text {th }}$ edition, UK: Law Business Research, 2018, pp. 377-388.

7. Florescu, C., 'Conflictul de interese în arbitrajul comercial. Independența și imparțialitatea arbitrilor' [Conflict of Interest in Commercial Arbitration. Independence and Impartiality of Arbitrators], 2010, Revista Română de Arbitraj (Romanian Review of Arbitration), no. 1, pp. 24-43.

8. Ionas-Salagean, M., Arbitrajul commercial [Commercial Arbitration], Bucharest: All Beck, 2001.

9. Iorgovan, A., Noua lege a contenciosului administrativ. Geneză și explicații [The New Law on Administrative Litigation. Genesis and Explanations], Bucharest: Roata, 2004.

10. Kidane, W.L., 'The Political and Cultural History of International Arbitration in Various Legal Traditions', in Kidane, W.L., The Culture of International Arbitration, OUP, 2017, e-book.

11. Leaua, C. and Baias, F. (eds.), Arbitration in Romania: A Practitioner's Guide, Wolters Kluwer, 2016.

12. Lefter, A. and Pigui, R.D., 'Reglementarea mecanismului de soluționare a disputelor în contractele ce încorporează condiții contractuale de tip FIDIC în dreptul românesc' [Regulation of the Dispute Settlement Mechanism in Contracts that Incorporate FIDIC Type 
Contractual Conditions in Romanian Law], furidice (legal blog), May 10, 2018, [Online] available at https:/www.juridice.ro/579508/reglementarea-mecanismului-de-solutionarea-disputelor-in-contractele-ce-incorporeaza-conditii-contractuale-de-tip-fidic-in-drep tul-romanesc.html, accessed on July 1, 2018.

13. Matei, E., 'Micula v. Romania. Commission Decision SA.385. Annotation', 2016, European State Aid Law Quarterly, vol. 15, no. 1, pp. 134-141.

14. Matei, E., 'The Chamber of Secrets: The Repudiation of the Investor-State Dispute Settlement Clause', 2015, Revista Română de Drept European, no. 4, pp. 83-97.

15. Oglinda, B., 'Despre validitatea și caracterul operant al clauzelor compromisorii încheiate de stat, autorități publice și alte persoane juridice de drept public, în contextul noului cod de procedură și al legislației speciale aplicabile' [About the Validity and the Effectiveness of the Arbitration Clauses Concluded by the State, Public Authorities and Other Public Legal Entities in the Context of the New Code of Civil Procedure and the Applicable Specific Legislation], 2014, Revista Transilvană de Științe Administrative, no. 1(34), pp. 81-97.

16. Piperea, G., 'Concepția monistă a noului Cod civil: intenţia şi realitatea' [The Monistic Conception of the New Civil Code: Intention and Reality], 2011, Revista Română de Drept al Afacerilor, no. 6, pp. 13-30.

17. Puie, O., 'Aspecte privitoare la instituția arbitrajului reglementată de către noul Cod de procedură civilă precum şi la modificările şi completările aduse procedurii de executare a hotărârilor arbitrale prin Legea nr. 138/2014 pentru modificarea şi completarea Legii nr. 134/2010 privind Codul de procedură civilă, precum şi pentru modificarea şi completarea unor acte normative conexe' [Aspects Regarding the Institution of Arbitration Regulated by the New Code of Civil Procedure as well as the Amendments and Completions Brought to the Procedure for the Execution of Arbitral Awards by Law no. (...)], 2015, Pandectele Române, no. 2, pp. 49-67.

18. Puie, O., Contractele administrative în contextul noului Cod civil şi al noului Cod de procedură civilă [Administrative Contracts in the Context of the New Civil Code and the New Code of Civil Procedure], Bucharest: Universul Juridic, 2014.

19. Sandru, D.M. and Ploesteanu, N., 'Executarea hotărârilor arbitrale pronunțate sub egida Centrului Internațional pentru Reglementarea Diferendelor cu privire la Investiții (ICSID/ CIRDI) împotriva României în contextul dreptului european' [The Execution of the Awards Rendered Pursuant to International Centre for Settlement of Investment Disputes Convention (ICSID) against Romania in the Framework of European Law], International Conference Civil Lawsuit and Legal Enforcement. Theory and Practice, 25-27 August 2016, Târgu Mureș, Romania, [Online] available at https://papers.ssrn.com/sol3/papers.cfm?ab stract_id=2830776, accessed on September 9, 2018.

20. Stoica, I.C., 'The New Architecture of the Rules of Arbitration of the Court of International Commercial Arbitration Attached to the Chamber of Commerce and Industry of Romania', 2019, Revista Română de Arbitraj [Romanian Arbitration fournal], no. 1, pp. 15-22.

21. Voicu, M., 'Extinderea jurisdicției arbitrale instituționalizate. Unele sugestii de lege ferenda supuse dezbaterii' [Extension of Institutionalized Arbitral Jurisdiction. Some Suggestions of Lege Ferenda Subject to Debate], furidice (legal blog), November 20, 2014, [Online] available at https://www.juridice.ro/347343/extinderea-jurisdictiei-arbitrale-institutional izate-unele-sugestii-de-lege-ferenda-supuse-dezbaterii.html, accessed on July 1, 2018. 
22. Zerhdoud, B., 'Case Comment: Ioan Micula, Viorel Micula, S.C. European Food S.A, S.C. Starmill S.R.L. and S.C. Multipack S.R.L. v. Romania', 2014, The fournal of World Investment \& Trade, vol. 15, pp. 1042-1052.

\section{Regulations}

1. United Nations, UN Convention on the Recognition and Execution of Foreign Arbitral Awards, adopted in New-York, on June 10, 1958.

2. Economic Commission for Europe of the United Nations, European Convention on International Commercial Arbitration, adopted in Geneva, on April 21, 1961.

3. Romanian Constitution, with modifications and additions made through the Law for Revision of the Romanian Constitution, no. 429/2003, published in the Official Journal of Romania, no. 758 from October 29, 2003.

4. Directive 2014/24/EU of the European Parliament and of the Council of 26 February 2014 on public procurement and repealing Directive 2004/18/EC, published in the Official Journal of the European Union L 94 from 28.03.2014.

5. Commission Decision (EU) 2015/1470 of 30 March 2015 on State aid SA.38517 (2014/C) (ex 2014/NN) implemented by Romania - Arbitral award Micula v. Romania of 11 December 2013 (notified under document C (2015) 2112), published in the Official Journal of the European Union L 232 from 04.09.2015.

6. Law no. 134/2010 on the Code of Civil Procedure (New Code of Civil Procedure), published in the Official Journal of Romania, no. 485 from July 15, 2010.

7. Law $287 / 2009$ on the Civil Code, published in the Official Journal of Romania, no. 511 from July 24, 2009.

8. Law no. 15/1990 concerning the reorganization of the state economic units as public companies and private companies, published in the Official Journal of Romania, no. 98 from August 8, 1990.

9. Law no. 29/1990 on judicial review of administrative action, published in the Official Journal of Romania, no. 122 from November 8, 1990.

10. Law no. 219/1998 on concessions, published in the Official Journal of Romania, no. 459 from November 30, 1998.

11. Law no. 651/2002 on the ratification of the Agreement between the Government of Romania and the Government of the Kingdom of Sweden regarding the mutual protection and support of investments, signed at Stockholm on May 29, 2002, published in the Official Journal of Romania, no. 901 from December 12, 2002.

12. Law no. 554/2004 on judicial review of administrative action, published in the Official Journal of Romania, no. 1154 from December 7, 2004.

13. Law no. 335/2007 regarding the Romanian Chambers of Commerce, published in the Official Journal of Romania, no. 836 from December 6, 2007.

14. Law no. $98 / 2016$ on public procurement, published in the Official Journal of Romania, no. 390 from May 23, 2016.

15. Law no. 99/2016 on utilities procurement, published in the Official Journal of Romania, no. 391 from May 23, 2016. 
16. Law no. 100/2016 on concession contracts, published in the Official Journal of Romania, no. 392 from May 23, 2016.

17. Law no. $101 / 2016$ on remedies in the public procurement field, published in the Official Journal of Romania, no. 393 from May 23, 2016.

18. Law no. 193/2013 modifying Government Emergency Ordinance no. 34/2006, published in the Official Journal of Romania, no. 387 from June 23, 2013.

19. Law no. 47/1992 on the organization and functioning of the Constitutional Court of Romania, published in the Official Journal of Romania, no. 101 from May 22, 1992.

20. Law no. 161/2003 on certain measures to ensure transparency in the exercise of public dignity, public office and in the business environment, the prevention and sanctioning of corruption, published in the Official Journal of Romania, no. 279 from April 21, 2003.

21. Law no. $215 / 2001$ on local public administration, republished in the Official Journal of Romania, no. 621 from July 18, 2006.

22. Government Emergency Ordinance no. 126/2005 on the representation of Romania or of public institutions before the International Court of Arbitration of the International Center for the Settlement of Investment Disputes, published in the Official Journal of Romania, no. 842 from September 19, 2005.

23. Government Emergency Ordinance no. 34/2006 regarding the award of the public procurement contracts, public works concession contracts and services concession contracts, published in the Official Journal of Romania, no. 418 from May 15, 2006.

24. Government Emergency Ordinance no. 109/2011 on Good Governance of Public Enterprises, published in the Official Journal of Romania, no. 883 from December 13, 2011.

25. Government Emergency Ordinance no. 26/2012 regarding certain measures of public expense reduction and of strengthening financial discipline, as well as of modification and addition to certain normative documents, published in the Official Journal of Romania, no. 392 from June 12, 2012.

26. Government Decision no. 1/2018 on the approval of the general and particular conditions of contract for certain categories of public procurement contracts related to the investment objectives financed by public funds, published in the Official Journal of Romania, no. 26 from January 11, 2018.

27. Order of the Economy Ministry and the Public Works and Housing Ministry no. $915 / 465 / 415 / 2008$ for approval of contractual conditions for works contracts, published in the Official Journal of Romania, no. 424, from June 5, 2008.

\section{Case-law}

1. ICSID, Washington, Case Ioan Micula, Viorel Micula and others v. Romania (ICSID Case No. ARB/05/20), Decision issued on December 11, 2013.

2. CJEU, Judgement of the General Court, June 18, 2019, Cases T-624/15, T-694/15 and T-704/15, European Foods SA and others v. European Commission, ECLI:EU:T:2019:423.

3. ECHR, Stefan and Stef v. Romania, Decision on application no. 24428/03 and 26977/03 from April 27, 2009, [Online] available at https://lege5.ro/gratuit/gqydmmbqga/hotarar ea-in-cauza-stefan-si-stef-impotriva-romaniei-din-27042009, accessed on September 24, 2017. 
4. Constitutional Court of Romania, Decision no. 203/2006, published in the Official Journal of Romania, no. 267 from March 24, 2006.

5. Constitutional Court of Romania, Decision no. 8/2007, published in the Official Journal of Romania, no. 73 from January 31, 2007.

6. Constitutional Court of Romania, Decision no. 395/2006, published in the Official Journal of Romania, no. 526 from June 19, 2006.

7. High Court of Cassation and Justice, Decision no. 3483 of June 29, 2010, [Online] available at https://legeaz.net/spete-contencios-inalta-curte-iccj-2010/decizia-3483-2010, accessed on July 1, 2019.

8. Timişoara Court of Appeal, Decision no. 1691 of September 27, 2011 [Online] available at http://legeaz.net/spete-drept-comercial/actiune-in-anularea-hotararii-arbitrale-1691-2011, accessed on January 23, 2017.

9. Mehedinti Court of Appeal, Decision no. 1081 of September 20, 2011 [Online] available at https://legeaz.net/spete-civil/necompetenta-instantei-declinarea-competentei-in-2002011, accessed on August 24, 2019.

10. Bucharest Court of Appeal, Decision no. 221 of November 17, 2015, [Online] available at http://legeaz.net/spete-drept-comercial-curtea-de-apel-bucuresti-2016/actiune-in-anular ea-hotararilor-arbitrale-17-11-2015-1be, accessed on January 23, 2019.

11. Court of International Commercial Arbitration from within the Chamber of Commerce and Industry of Romania, Arbitration Decision no. 153 of June 29, 2010, unpublished.

12. Court of International Commercial Arbitration from within the Chamber of Commerce and Industry of Romania, Arbitral Decision no. 177 of July 4, 2006, unpublished. 